\title{
Endomembrane Reorganization Induced by Heavy Metals
}

\author{
Monica De Caroli ${ }^{1}$, Antonella Furini ${ }^{2}$, Giovanni DalCorso ${ }^{2}$ (D), Makarena Rojas ${ }^{1}$ and \\ Gian-Pietro Di Sansebastiano 1,*(D)
}

1 Department of Biological and Environmental Sciences and Technologies (DiSTeBA), University of Salento, 73100 Lecce, Italy; monica.decaroli@unisalento.it (M.D.C.); makarena.rojas@unisalento.it (M.R.)

2 Department of Biotechnology, University of Verona, 37134 Verona, Italy; antonella.furini@univr.it (A.F.); giovanni.dalcorso@univr.it (G.D.)

* Correspondence: gp.disansebastiano@unisalento.it; Tel.: +39-0832-298-714

Received: 28 February 2020; Accepted: 7 April 2020; Published: 9 April 2020

\begin{abstract}
Plant cells maintain plasmatic concentrations of essential heavy metal ions, such as iron, zinc, and copper, within the optimal functional range. To do so, several molecular mechanisms have to be committed to maintain concentrations of non-essential heavy metals and metalloids, such as cadmium, mercury and arsenic below their toxicity threshold levels. Compartmentalization is central to heavy metals homeostasis and secretory compartments, finely interconnected by traffic mechanisms, are determinant. Endomembrane reorganization can have unexpected effects on heavy metals tolerance altering in a complex way membrane permeability, storage, and detoxification ability beyond gene's expression regulation. The full understanding of endomembrane role is propaedeutic to the comprehension of translocation and hyper-accumulation mechanisms and their applicative employment. It is evident that further studies on dynamic localization of these and many more proteins may significantly contribute to the understanding of heavy metals tolerance mechanisms. The aim of this review is to provide an overview about the endomembrane alterations involved in heavy metals compartmentalization and tolerance in plants.
\end{abstract}

Keywords: heavy metals; endomembranes; cell wall; remodeling; cellular trafficking; plant stress

\section{Introduction}

Heavy Metals ( $\mathrm{Pb}, \mathrm{Zn}, \mathrm{Ni}, \mathrm{Cd}, \mathrm{Fe}, \mathrm{Cr}, \mathrm{Cu}$, etc.) and Metalloids (As, $\mathrm{Se}, \mathrm{Sb}$ ) are naturally present in the Earth's crust, some of them are essential for life such as $\mathrm{Fe}, \mathrm{Cu}, \mathrm{Zn}, \mathrm{Co}, \mathrm{Mn}, \mathrm{Mo}$, and $\mathrm{Ni}$ and are required as micronutrients that act as cofactors in biochemical reactions or play other physiological role into the cell and become toxic when in excess. Other elements, such as $\mathrm{Cd}, \mathrm{Hg}$, and $\mathrm{Pb}$ do not have biological functions and are toxic even if present at low concentration [1,2]. Here, for simplicity, the term Heavy Metals (HMs) refers to both heavy metals and metalloids. The content of HMs in the environment has increased in the last decades due to anthropogenic actions [3,4]. Indeed, mining and industrial activities, agricultural practices, and urban traffic release HMs into the environment. Such transition elements cannot be further degraded or destroyed and the exposition to high level is toxic to all living organisms including humans [5]. In addition, crop yield can be affected by excess HM in soils and plants represent the main entry pathway of HMs into the food chain. In the past decades, the use of model systems has led to a significant progress on the identification and characterization of candidate genes involved in HM movement and destination inside the plant cell, and on their role in physiological processes. These achievements and the future work investigating the molecular mechanisms underneath plant resistance to HMs will allow to produce healthy food and 
biofortified food crops with increased concentration of essential HM [6], and also to tailor plants ideal for phytoremediation [7].

Some species are defined metal hyperaccumulators because they are naturally able to accumulate extremely high concentrations of HMs in their aerial tissues [8]. This peculiar trait occurs without toxicity symptoms and hence it implies hypertolerance $[9,10]$. The most extreme example is represented by Sebertia acuminata, a Ni hyperaccumulator species in which the Ni content in latex can reach $26 \%$ of the dry weight [11]. Two hyperaccumulator species Arabidopsis halleri and Noccaea caerulescens (formerly Thlaspi caerulescens) are suitable models for physiological and genetic analyses of the metal hyperaccumulation trait thanks to their high similarity and extensive synteny with Arabidopsis thaliana [12]. Both species hyperaccumulate $\mathrm{Zn}$ and $\mathrm{Cd}$ (although with certain differences among populations); and N. caerulescens ecotypes endemic on serpentine soils are also Ni hyperaccumulator [13]. Another hyperaccumulator species identified more recently is represented by the fern Pteris vittata [14]. This fern can hyperaccumulate As and it represents an interesting model system to investigate As metabolism in plants [15]. During the past decades, a variety of molecular approaches brought to the identification of candidate determinants controlling the hyperaccumulation trait. This process requires, indeed, increased metal uptake and xylem loading as well as enhanced metal accumulation and detoxification in shoots. A breakthrough emerged from comparative physiological and molecular analyses of hyperaccumulators and related metal sensitive plant varieties, highlighting that the hyperaccumulation trait does not rely on a new resistance mechanism acquired during evolution, but it rather depends on the different regulation and activity diversification of proteins which are involved in metal handling, accumulation, and detoxification (e.g., metal transporters, chelators, and proteins involved in stress responses) [15-18].

In recent years, increasing attention has also been paid to the effect on the environment of nanoparticles, atomic or molecular aggregates with nano-dimension (between 1 and $100 \mathrm{~nm}$ ), an inevitable product of volcanic natural events or accidental industrial applications [19]. Engineered nanoparticles, for example silver nanoparticles (AgNPs), are used in agriculture as plant growth and fruit ripening stimulators [20] or as fungicides [21]. Plants can absorb metallic nanoparticles present, for example, in heavy metal laden effluents from industrial sources [22]. Plants can also accumulate metallic species in the shape of nanoparticles, as observed in hydroponic studies. In those conditions, Gardea-Torresdey [23,24] first demonstrated the presence of metal nanoparticles of gold and silver in leaves of alfalfa phytoaccumulator species. Equally, the presence of nanoparticles of silver with size close to $50 \mathrm{~nm}$ has been observed in Brassica juncea and Medicago sativa [25]. Likewise, the uptake of heavy metals in the form of nanoparticles has been evidenced by plants grown autogenously in polluted areas. In leaves of Dittrichia viscosa and Cichorium intybus, the presence of nanoparticles was observed using dynamic light scattering, X-ray fluorescence, and transmission electron microscopy [26].

Up to now, research has deeply investigated the physiological and molecular aspects of the HM effect and transport into the plant body or the plant cell, but only little information has been published upon the effects of HM on the organization of the cell endomembrane system. It appears clear that this extended compartment could play a role in the turnover of particular transporters, influencing their activity and therefore effect on plant tolerance towards HM stress. Therefore, we aim here to give an overview of the morphological alteration showed by endomembrane compartments upon stress due to excess metal ions.

\section{Metal Ions Movement Across Membranes}

Plants are able to transport metal ions according to their growth and development, dispatching them to growing organs and to the cell compartments where they are integrated into biological functions. For instance, a fine control of metal trafficking is required in energy-handling organelles, such as chloroplasts and mitochondria, in which metal ions are involved in electron transport, but could cause serious oxidative damage [27]. Toxic HMs are also embedded into metal transport through the plant tissues and body. A variety of fine mechanisms are enacted by plants to survive and to 
maintain a functional cell metabolism in the presence of toxic HMs. These can be aimed either to avoid or tolerate the stress. Avoidance includes the mechanisms protecting the plant cell from HMs entering the protoplast, while tolerance is accomplished by those mechanisms enabling the plant to neutralize toxic metals (or their toxic effects) or to remove them from sensitive compartments (by sequestration in the apoplast or in the vacuole). In this context, metal transporters assume a pivotal role, being transmembrane proteins able to accomplish metal transport across biological membranes. These proteins are involved in root uptake, root-to-shoot translocation, and maintenance of cellular metal homeostasis by distributing metal ions into/out of cellular organelles and compartments. There is a great dynamism in metal trafficking into the cells and the plant body, which is mainly due to: (i) the fact that sharing similar chemical proprieties, some essential and toxic HMs share also the same uptake pathways; (ii) related transporters may compete for cation transport, thanks to their broad substrate affinity; (iii) members of the same transporter family may show different tissue expression and/or subcellular localization [28]. Metal transporters have been divided into families, according to sequence homology. The main families of metal transporters which are involved in the uptake of metals into the cytosol (influx transporters), or in its compartmentalization into cellular compartments and organelles or extrusion from the cellular environment (efflux transporters) are ZIPs, natural resistance-associated macrophage protein (NRAMPs), cation diffusion facilitator (CDFs), and heavy metals ATPase (HMAs), but also members of YSL, CAX, and MATE transporter families are involved [29].

Members of the ZIP family (Zinc-Iron Permease, also known as ZRT, IRT-like proteins) are implicated in the transport of a variety of metals, including the essential $\mathrm{Fe}, \mathrm{Zn}, \mathrm{Cu}$ and $\mathrm{Mn}$, and the toxic $\mathrm{Cd}[1,30]$. Their name is due to the first three described members of this family, involved in transport of Zn in yeast and Fe in A. thaliana, ZRT1 and ZRT2, and IRT1 respectively. In A. thaliana, 18 sequences have been identified as putative members of the ZIP family, and their role is still under investigation. Some proteins seem to be involved in intracellular influx of ions and are located on the plasma membrane: AtZIP2, ZIP4, and ZIP9 in A. thaliana and ZNT (homologous to ZIP4) in N. caerulescens are likely to play a role in uptake of $\mathrm{Zn}, \mathrm{Mn}$, and $\mathrm{Cd}[30,31]$. Interestingly, Fe transporters such as IRT1 and IRT2 are able to take up Cd in both Oryza sativa and A. thaliana [32]. Other ZIP transporters may be responsible for metal distribution into cellular compartments, as AtIRT2, which is located in endo-membranes vesicles contributing to Fe transport into these compartments [33,34] and OsZIP1, showing a dual location on the plasma membrane and on the endoplasmic reticulum upon normal growth conditions and limiting $\mathrm{Zn}, \mathrm{Cu}$, and $\mathrm{Cd}$ accumulation in rice tissues [35].

Metal transporters that belong to the natural resistance-associated macrophage protein (NRAMP) family have been shown to transport a variety of metals across membranes, and as the members of the previously mentioned ZIP family, generally display poor selectivity towards divalent metal cations [36]. Generally characterized by ten to twelve transmembrane domains with a predicted transport motif between the VIII and IX transmembrane helices, NRAMP transporters are described to have broad metal specificity with the same protein able to interact with few metals. The metal transport capacity of NRAMP proteins has been demonstrated by complementation of yeast mutants impaired in metal uptake [37]. Members of this family can reside in the plasma membrane, while others sit on the tonoplast, highlighting a possible function in adjusting cytosolic metal concentration or releasing metals from the vacuole [36]. In A. thaliana and O. sativa, there are 6 and 7 NRAMPs respectively. AtNRAMP1 is upregulated in the root under Mn deficiency and it is believed to be a high affinity Mn transporter with plasma membrane localization [29]. AtNRAMP3 and AtNRAMP4, as well as AtNRAMP1, can complement yeast deficient in either Mn or Fe uptake. They were localized in vivo on the tonoplast and are able to transport Fe, Mn, and Cd [38]. AtNRAMP4 was also identified as part of the vacuolar proteome in A. thaliana [39]. Less is known for AtNRAMP2, AtNRAMP5, or AtNRAMP6. The study of NRAMPs in rice shows that OsNRAMP3, but not OsNRAMP5, responds to environmental changes in Mn availability. OsNRAMP3 was localized on the plasma membrane and when $\mathrm{Mn}$ is in excess, it is internalized in vesicles to be degraded as part of a post-translational regulation in response to environmental nutrient availability [29]. 
The third large family of metal transporters is grouped under the name of cation diffusion facilitator (CDF), whose members are phylogenetically ubiquitous and have been identified in bacteria, yeast, plants, and mammals [40]. In plants, CDF proteins are also identified as metal tolerance proteins (MTPs) and are mainly involved in the efflux of cations from the cytoplasm through sequestration into internal compartments or through efflux from the cell [41]. Indeed, most MTPs are localized in the tonoplast, working as antiporters of $\mathrm{Zn}, \mathrm{Cd}$, and $\mathrm{Ni}$ [42] or in other subcellular compartments, such as AtMTP11, which resides within a punctate endomembrane compartment consistent with either trans-Golgi or pre-vacuolar organelles. Moreover, being highly expressed in the leaf hydathodes, AtMTP11 seems to be involved in vesicular trafficking and exocytosis of excess Mn at secretory tissues where Mn will be excreted rather than stored $[29,41]$.

The last family of metal transporters that will be analyzed in this review is defined heavy metals ATPase (HMA) and groups P-Type ATPase proteins able to transport metal ions such as $\mathrm{Ca}, \mathrm{Cu}, \mathrm{Zn}, \mathrm{Cd}$, $\mathrm{Co}, \mathrm{Pb}$, and $\mathrm{Mn}$ across membranes upon ATP hydrolysis [43]. HMAs have been extensively studied in A. thaliana and O. sativa: their localization includes the plasma membrane, the tonoplast, and the cellular endomembrane system. HMAs are involved in delivering $\mathrm{Zn}$ and $\mathrm{Cu}$ in and out of the chloroplast and into plastid sub-compartments, in $\mathrm{Zn}$ and $\mathrm{Cd}$ xylem loading, in detoxification of $\mathrm{Zn}, \mathrm{Cd}, \mathrm{Co}$, and $\mathrm{Pb}$ by pumping them into the vacuole [43]. Interestingly, two particular P-Type ATPases, AtECA1, and AtECA2 which are located in the endoplasmic reticulum and the Golgi apparatus, respectively, function in carrying $\mathrm{Mn}$ ions from the cytosol to the respective compartment [29].

Heavy metals cross membranes not only by transporters but also through the water channel called aquaporin (AQPs). AQPs belong to the family of Major Intrinsic Proteins (MIPs) [44] that transport other molecules of great physiological interest in addition to water [45] and are possibly engaged in structural roles [46-48]. In plants, MIPs form a large superfamily of proteins with more than thirty identified members in A. thaliana [49] and Populus trichocarpa [50].

Several studies report that AQPs are differentially expressed in response to HM stress, but patterns are not uniform among species. For example, $\mathrm{HMs}^{\prime}$ stress in Solanum torvum and $A$. thaliana induces a general down regulation of aquaporin transcripts [51-53], while in $B$. juncea induces an up-regulation of a PIP1 aquaporin able to improve HM resistance when over-expressed in transgenic plants [54]. Several studies report that aquaporins can undergo modifications, such as glycosylation [55] or ubiquitination [56], which accompany a stress-induced or development-induced re-localization. Once entered the cell environments, free cytosolic metal ions are sequestered into a particular compartment (e.g., the vacuole, an organelle of the endomembrane systems) or follow chelation reactions. The cell environment is rich in HM chelating compounds and molecules, represented by thiol-rich peptides, phytochelatins (PCs), organic acids, such as citric acid or malic acid, glutathione, histidine, and other amino acids, metallothioneins, and nicotianamine [57-63]. Alteration of endomembrane compartmentalization is then an important symptom of HM-related stress.

\section{Metal Ions Effects on Membranous Compartments}

\subsection{Endoplasmatic Reticulum}

A role of endoplasmic reticulum (ER) in HM tolerance has been well reported in yeast. In Schizosaccharomyces pombe, the Zhf (Zinc homeostasis factor) protein, located in the ER and in the nuclear envelope, detoxifies the cytosol from $\mathrm{Zn}$ ions by accumulating them in the ER. S. pombe zhf mutant cells have increased $\mathrm{Zn}$ and $\mathrm{Cu}$ sensitivity and, at the same time, increased $\mathrm{Cd}$ and $\mathrm{Ni}$ tolerance [28]. Gardarin and co-workers identified the ER as the principal target of Cd toxicity in Saccharomyces cerevisiae [64]. Additionally, mammalian cells show the induction of typical markers of ER stress after $C d$ exposition [65]. A number of CDFs located on ER membranes, e.g., mammalian ZnT2 and ZAT from A. thaliana, have been shown to mediate $\mathrm{Zn}$ tolerance as well as increased Zn accumulation [66]. In plants, the ER was reported to be important in $\mathrm{Pb}$ detoxification. In epidermal cells of Allium cepa $\mathrm{Pb}$ toxicity was reduced by its accumulation mainly in ER-derived vesicles in the 
cytoplasm [67]. Cd exposition did not induce the same ER-derived vesicles even if the ER was altered in comparison with control condition [67].

AtNIP1;1 is an aquaglyceroporin able to transport arsenite (As[III]) and antimony, recently localized in vivo on ER membrane [48]. Its knock-out mutant (nip1;1ko) is resistant to toxic concentrations of As[III] but tolerance to arsenite is not due to a reduced uptake through the PM since in two different and independent studies $[48,68]$ nip1;1ko lines were shown to regularly uptake As(III). If nip1;1ko has no effect on As(III) uptake it must control compartmentalization of the metalloid. Indeed this mutant or transgenic lines expressing tagged variants of NIP1;1 showed altered profiles for other elements uptake such as a reduction for $\mathrm{Cu}$ (II) and an increase for $\mathrm{Zn}$ (II) [48], confirming a role in metals and metalloids homeostasis. NIP1;1 was shown to interact with the vacuolar SNARE SYP51 and it is possible that through this interaction it regulates the vacuolar detoxification capacity. A different explanation for ko mutant resistance to arsenite is that the most important targets of As(III) toxicity are in the ER. The morphological changes of this marker under the effect of HMs have not been characterized.

Sequestration of $\mathrm{Mn}$ in the ER is an important mechanism of tolerance in plants but also other membranes are involved [69]. Four ER-type calcium ATPases (ECAs) in A. thaliana (AtECA1-4) and three in rice (OsECA1-3), belonging to the $\mathrm{Ca}^{2+}$-ATPase subfamily, are localized in part to the ER [69] and in part to the Golgi compartments [69,70]. AtYSL4 and AtYSL6 are reported to be localized on internal membranes resembling the ER in A. thaliana but also to vacuole membranes. Other elements of Mn tolerance mechanisms are located on trans-Golgi network membranes and tonoplast [69]. It is evident that further studies on dynamic localization of these and many more proteins is necessary.

\subsection{Golgi Apparatus}

HMs can reach the Golgi apparatus (GA) through the secretory traffic but also directly from the cytosol thanks to specific transporters [71]. The most studied transporters localized in the GA membranes are CDFs. These antiporters are mostly localized in the tonoplast but were also found in the GA. For example OsMTP11 from rice, HvMTP8.1, and HvMTP8.2 from barley, PtMTP11.1, and PtMTP11.2 from P. trichocarpa as well as BmMTP10 and BmMTP11 from Beta vulgaris sequester Mn into the GA [69]. AtMTP11 is involved in Mn tolerance and is localized to a punctate endomembrane compartment probably in the trans-Golgi, but not to the plasma membrane and vacuole where other MTPs are localized (ShMTP1, OsMTP8.1, and OsMTP8.2). Its overexpression increases tolerance to Mn toxicity [72]. A recent work on O. sativa used a tagged version of the transporter, MTP11:GFP to evidence co-localization with trans-Golgi markers and not with pre-vacuolar compartment (PVC) markers. Anyhow, knockout of MTP11 in wild-type rice did not affect tolerance and accumulation of Mn or other HMs but caused secondary effects on fertility [73]. Only as second mutation in mtp8.1 knock-out lines was able to induce Mn sensitivity. These proteins must be kept in the correct location. It is not yet clear if these mechanisms lead to exocytosis as shown by Peiter at al., [74] or to PVC and vacuole as shown by other authors working with higher concentrations of Mn [72].

Effect of HMs, or adaptation to them, can involve GA in different ways. Transcriptomic studies under Cd stress have shown in unicellular algae Dunaliella, the overexpression of genes involved in carbohydrate metabolic process and located in ER and GA [75]. Polysaccharides biosynthesis is important in algae to counteract salt and drought stress but must also be important to neutralize pollutants such as HMs by secreting extracellular polymers [76].

Morphological alteration induced by HMs at GA level can reveal a specific relation between this organelle and the HM transport or accumulation. Whether this relation is direct or indirect remains to be investigated case by case. Eleftheriou et al. [77] monitored in time the effect of $\mathrm{Cr}(\mathrm{VI})$ exposures in A. thaliana roots. Plastids, mitochondria, GA, and vacuoles suffered the most evident damage; ER, cytoplasm, nuclei, and cell walls showed intermediate damage. GA was shown to suffer an early effect on morphology starting with an interesting semi-circular conformation, enclosing cytoplasmic material and producing at the end of the process ring-like structures containing translucent material [77]. 
Once more it is not possible to define if these effects are directly induced by $\mathrm{Cr}$ or by $\mathrm{Cr}$-induced production of ROS [77].

$\mathrm{Cr}(\mathrm{VI})$ stress $\left(100 \mu \mathrm{M}\right.$ potassium dichromate $\left.\left(\mathrm{K}_{2} \mathrm{Cr}_{2} \mathrm{O}_{7}\right)\right)$ appeared to be specific: after $48 \mathrm{~h}$ Golgi bodies were severely disorganized, consisting of a single circular cisterna, residual, or swollen cisternae. Additionally, ER formed large aggregations of parallel or concentric, ribosome-bearing, non-swollen cisternae. Sometimes, amorphous electron dense material was trapped between ER cisternae [77]. With Golgi, also mitochondria and plastids morphology was drastically altered even if their double-membrane envelopes remained structurally intact [77].

When considering the alteration of GA, dictiosomes mobility associated to cytoskeleton has to be considered. In fact indirect effect on endomembranes may derive from cytoskeleton disruption, like in the case of $\mathrm{Cd}$ stress that perturb both endocytosis and exocytosis because it disrupts the "tracks" (actin filaments) for vesicle transport [78]. The effect of $\mathrm{Cd}$ on actin filaments was studied in A. thaliana root hairs. $5 \mu \mathrm{M} \mathrm{Cd}$ destroyed the arrangement of actin filaments, changing them from a longitudinal to a transverse array. With increasing Cd concentrations, longitudinal AFs completely disappeared. The alteration in actin cytoskeleton derives from alteration of Ca metabolism and transport because many cytoskeletal proteins are sensitive to changes in Ca. For example Ca can be replaced by $\mathrm{Cd}$ in the crystal structure of the Ca-dependent actin-severing protein gelsolin activating the association of gelsolin with actin cytoskeleton, with gelsolin's severing properties [78]. A more recent study on Cd stress effects on Picea wilsonii pollen germination and tube growth [79] investigated the effects on ER, GA, and vacuoles morphology. The study apparently ignored the effects on cytoskeleton [78].

\subsection{Multi-Vesicular Bodies}

Vacuolar traffic and autophagy are important in homeostasis and detoxification processes but are often interconnected to ER and GA plasticity and involve the formation of the so-called Multi Vesicular Bodies (MVBs) [80-85]. A microarray study in Populus stressed by $\mathrm{Zn}$ allowed the identification of an AQP of NIP type, AQUA1 [86], down-regulated in both leaf and root tissues, possibly with the effect to reduce transpiration, water/Zn uptake, and leaf growth, probably for protecting photosynthetic tissues and for enhancing poplar tolerance [87]. The localization of AQUA1-GFP was also studied in $A$. thaliana and N. tabacum [85] showing a diffused distribution but also showing association with markers such as Cherry-BP80 and RFP-ATG8f in large MVBs. Treatments with $100 \mu \mathrm{M}$ and $200 \mu \mathrm{M}$ Zn affected the localization pattern of AQUA1-GFP in transiently transformed protoplasts reducing the number of fluorescent structures increasing their size. The co-treatment with $\mathrm{Zn}$ seemed to influence the reaction to $10 \mu \mathrm{M}$ of $\mathrm{HgCl}_{2}$. AQUA1 is a mercury sensitive aquaporin and the reduction of $\mathrm{Hg}$ dependent alterations in the presence of $200 \mu \mathrm{M}$ of $\mathrm{Zn}$ and the significant increase in vesicles number in A. thaliana protoplasts under excess $\mathrm{Zn}$, suggesting a possible protective role of this protein. $\mathrm{Zn}$ treatments caused AQUA1-related MVBs' aggregation in response to $\mathrm{Zn}$ stress with the effect to remove aquaporins from the ER. This may reduce ER permeability to $\mathrm{Zn}$ or concentrate all the transport in the MVBs. A similar mechanism of re-localization was reported also for the human aquaporin-2 in response to hormone-signaling [88] and for PIPs in A. thaliana roots treated with $\mathrm{NaCl}$ and salicylic acid [89].

The formation of separated compartments is a general mechanism to contrast HMs stress in both plants and animals. When the induced compartments are related to $\mathrm{Zn}$ stress were named 'zincosomes' $[90,91]$. In plants, these compartments evolve as pro-vacuoles and may be considered as separated vacuoles. In fact, $\mathrm{Zn}$ detoxification in A. thaliana appears mediated by specific vacuolar metal transporter such as AtMTP1 and AtHMA3 [92,93]. AtMTP1 is normally localized on tonoplast and mtp1 ko mutants does not form Zn-induced vesicles [94]. Despite the possibility to evidence morphological effects on MVBs, their formation is certainly strictly related to the vacuole.

\subsection{Vacuole}

Vacuoles are essential to cope with HMs stress but are involved in very different pathways. In general, vacuolar sequestration of HMs reduces concentration of HM ions in the cytosol alleviating 
HM toxicity affecting cytosolic biochemical reactions. The first functionally characterized CDF for Mn transport, ShMTP1, was isolated from a tropical legume with higher Mn tolerance and was localized to the tonoplast [69]. Overexpression of ShMTP1 confers Mn tolerance in yeast cells and A. thaliana via sequestration of Mn into the vacuoles [69,95]. AtMTP1 also functions as a $\mathrm{Zn}^{2+} / \mathrm{H}^{+}$antiporter transporting cytosolic $\mathrm{Zn}^{2+}$ into vacuoles [96]. Similarly, others CDFs are localized in the tonoplast working as antiporters of $\mathrm{Zn}^{2+} / \mathrm{H}^{+}, \mathrm{Cd}^{2+} / \mathrm{H}^{+}$, and $\mathrm{Ni}^{2+} / \mathrm{H}^{+}[42]$.

Endomembranes react to the HM stress changing traffic dynamic and in the case of vacuoles they change shape and size. The effects of various HM ions (both essential and non-essential) were studied in different conditions. Zn caused tubular vacuoles to turn spherical within 15 min in the hyphae of a Paxillus involutus [97]. Four days exposure to a subtoxic concentration of Zn, approximately a threefold and sevenfold increase in vacuolar volume fraction occurred in O. sativa and Triticum aestivum, while a similar increase was absent in Secale cereale. The $\mathrm{Zn}$-induced vacuolation was proposed to represent a compartmentalization mechanism to reduce toxicity [98]. Ultrastructural analysis by transmission electron microscopy revealed that a 3-days exposure of a unicellular alga Chlamydomonas acidophila to a concentration of Cd close to the EC50, induced to doubling the vacuolar volume with the appearance of vacuolar deposits of phosphate and $\mathrm{Cd}$. $\mathrm{Cu}$ and $\mathrm{Zn}$ treatment did not induce the same effects, suggesting those are metal-specific responses [99]. Increased vacuolation after $\mathrm{Cd}$ $(20 \mu \mathrm{M})$ treatment was observed in meristematic root cells of 3-day-old seedlings of $A$. thaliana [100]. The cellular morphometry of root tip cortical cells of $A$. thaliana transformed with GFP fused to a tonoplast protein was studied correlating $\mathrm{Cd}$ concentration and vacuolation [100].

The effect of $\mathrm{Cd}$ in different systems can be heterogeneous. $\mathrm{Cd}$ induced the formation of small vesicles in suspension-cultured cells of Nicotiana tabacum [101] or had no effect at all on endomembranes of radish leaves cells [102]. The heterogeneity may be due to genotypic or experimental differences and more variability occur due to the effect of different HMs (some reviewed in [81]).

Endomembranes remodeling was studied in A. thaliana under Cr(VI) stress [77]. Several severe effects were observed: bulbous outgrowths of nuclei and plastids, intranucleoplasmic macrotubules, vesicular structures budding at the edges of ER cisternae, and the formation of lipid droplets in the cytoplasm or in close association with plastids.

In $\mathrm{Cr}(\mathrm{VI})$-treated cells, most vacuoles retained their integrity but they contained several inclusions, the most usual of which were variously shaped aggregations of granular precipitates. Other inclusions were irregular, membrane-bound structures, containing very dense granular material. Other frequently reported effects of $\mathrm{Cr}$ stress refer to membrane injury, vacuole disruption, and cytoplasm dilution due to mixing with vacuolar contents [77].

\section{Metal Ions and the Cell Wall}

Cell wall is the first barrier against HM entry into plant cells. HM ions can bind to the functional groups of all cell wall components but most of divalent and trivalent metal cations are bound by polysaccharides abundant in carboxyl groups [62,103,104]. HMs accumulated and precipitated in the cell wall are efficiently inactivated [104,105].

The degree of methylesterification and acetylation of pectin decreases its affinity for HM. In Silene paradoxa, a copper-tolerant cultivar differentiated from a copper-sensitive cultivar is shown to have in the root a reduced pectin content associated with an increased methylesterification [106].

The growing tips of apical cells of Funaria hygrometrica protonemata showed cell wall thickenings induced by $\mathrm{Pb}^{2+}$. The thickenings were evidenced by specific immunolabelling. The most evident effect was the appearance high amount of low-esterified (JIM5 epitope) and unesterified (PAM1 epitope) homogalacturonans. Both compounds, absent in the cell wall of control protonemata, are able to bind and immobilize $\mathrm{Pb}^{2+}$. Furthermore, $\mathrm{Pb}^{2+}$ induced an increasing of internalization by endocytosis of low-methylesterified pectins, $\mathrm{Pb}$ bound, from the cell wall to the vacuoles of protonemata cells. Interestingly, the cell wall thickenings were separated from plasma membrane by callose layer, compound impermeable to HMs, likely in order to prevent the internalization of $\mathrm{Pb}$ pectins into the 
cell $[62,107]$. High concentration of HMs led the formation of thickenings in the cell wall of root cell of Vicia faba, with the peculiarity that the cells with HMs deposits only in thickened cell wall did not appear damaged, while those with HMs deposits within the cell was seriously damaged. These observations suggested that the cell wall is involved in protection events from HMs in plants [108,109].

There are several examples of metal accumulation in the cell wall. The common reed (Phragmites australis) is considered to be a plant with a high phytoremediation potential. When exposed to high $\mathrm{Zn}$ levels, the metal was accumulated mainly in the cell wall [105]. The moss Scopelophila cataractae uses pectins to bind $\mathrm{Cu}$ in the cell walls and it can normally grow in $\mathrm{Cu}$ excess condition without suffering symptoms of toxicity [110]. The hyperaccumulator $N$. caerulescens and the fern Lycopodium japonicum bind in the cell wall about $50 \%$ of HMs [111,112]. In the water plant Elodea canadensis, up to $70 \%$ of $\mathrm{Cd}$ can be bound to the cell wall [113].

Some species enhance lignin biosynthesis in response to HM exposure, suggesting that lignin in plant cell walls may play a role in sequestering HMs [114,115]. It was reported that $\mathrm{Cu}$ has a positive effect on the biosynthesis of lignin [116]. In Panax ginseng exposed to a high level of Cu, lignin biosynthesis was enhanced [117]. In M. truncatula, high levels of Al induced increased activity of peroxidases and lignin deposition correlated to root growth inhibition presumably due to cell wall stiffening as a consequence of increased lignin deposition [118].

Chemical changes due to HMs can be revealed by the interference with water absorption due in part to the inactivation of water channel proteins and in part to a decreased cell wall extensibility or elasticity derived by the cross-linking of the pectin carboxyl groups in the walls with heavy metals [119]. The chemical transformation of the cell wall is anyhow not so important in all those cases where resistant mutants missing some transporters or channels show to recover a normal growth. In the case of As(III) for example, root growth inhibition is not depending on cell wall since the mutant missing one AQP able to transport As (NIP1.1, independent from cell wall deposition or modification), is fully resistant and grows normally [48].

\section{Conclusions}

The specific mechanisms induced by HMs causing endomembrane remodeling are largely uncharacterized. The most studied phenomenon is the extension of vacuolar system and still the mechanism is unknown [81]. The lack of knowledge is surprising considering that many genes involved in vesicular traffic such as SNAREs [120] have been identified. Toxic HM ions interfere with the cellular and molecular machinery associated with membrane traffic but it is also true that membranes composition and organization contribute to cope with HM effects providing additional tools to a future improvement of phytoremediation approaches [121]. An increased knowledge on membrane markers behavior under the effect of HMs-related stress may provide new tools in the study of these relevant aspects of plant physiology. The study of endomembrane adaptation to HMs effect on aspect should receive attention in the context of HM stress.

Author Contributions: Conceptualization, G.-P.D.S.; writing—original draft preparation G.-P.D.S., M.D.C., G.D., A.F.; writing—review and editing, G.-P.D.S., A.F., M.D.C., G.D., M.R.; supervision, G.-P.D.S., A.F., G.D.; All authors have read and agreed to the published version of the manuscript.

Funding: This research received no external funding.

Conflicts of Interest: The authors declare no conflict of interest.

\section{References}

1. Hall, J.L.; Williams, L.E. Transition metal transporters in plants. J. Exp. Bot. 2003, 54, 2601-2613. [CrossRef]

2. Patra, M.; Bhowmik, N.; Bandopadhyay, B.; Sharma, A. Comparison of mercury, lead and arsenic with respect to genotoxic effects on plant systems and the development of genetic tolerance. Environ. Exp. Bot. 2004, 52, 199-223. [CrossRef] 
3. Vareda, J.P.; Valente, A.J.M.; Durães, L. Assessment of heavy metal pollution from anthropogenic activities and remediation strategies: A review. J. Environ. Manag. 2019, 246, 101-118. [CrossRef]

4. DalCorso, G.; Fasani, E.; Manara, A.; Visioli, G.; Furini, A. Heavy metal pollutions: State of the art and innovation in phytoremediation. Int. J. Mol. Sci. 2019, 20, 3412. [CrossRef]

5. Rehman, K.; Fatima, F.; Waheed, I.; Akash, M.S.H. Prevalence of exposure of heavy metals and their impact on health consequences. J. Cell. Biochem. 2018, 119, 157-184. [CrossRef] [PubMed]

6. Nestel, P.; Bouis, H.E.; Meenakshi, J.V.; Pfeiffer, W. Biofortification of Staple Food Crops. J. Nutr. 2006, 136, 1064-1067. [CrossRef] [PubMed]

7. Rai, P.K.; Kim, K.H.; Lee, S.S.; Lee, J.H. Molecular mechanisms in phytoremediation of environmental contaminants and prospects of engineered transgenic plants/microbes. Sci. Total Environ. 2020, 705, 135858. [CrossRef] [PubMed]

8. Baker, A.J.M.; Brooks, R.R. Terrestrial higher plants which hyperaccumulate metallic elements-A review of their distribution, ecology and phytochemistry. Biorecovery 1989, 1, 81-126.

9. Verbruggen, N.; Hermans, C.; Schat, H. Molecular mechanisms of metal hyperaccumulation in plants. New Phytol. 2009, 181, 759-776. [CrossRef]

10. Krämer, U. Metal Hyperaccumulation in Plants. Annu. Rev. Plant Biol. 2010, 61, 517-534. [CrossRef]

11. Jaffré, T.; Brooks, R.R.; Lee, J.; Reeves, R.D. Sebertia acuminata: A hyperaccumulator of nickel from New Caledonia. Science 1976, 193, 579-580.

12. Fasani, E. Plants that Hyperaccumulate Heavy Metals. In Plants and Heavy Metals; Furini, A., Ed.; Springer Briefs in Molecular Science: Verona, Italy, 2012; pp. 55-74.

13. McGrath, S.P.; Sidoli, C.M.D.; Baker, A.J.M.; Reeves, R.D. The potential for the use of metal-accumulating plants for the in situ decontamination of metal-polluted soils. In Integrated Soil and Sediment Research: A Basis for Proper Protection; Eijsackers, L.P., Hamers, T., Eds.; Kluwer Academic Publishers: Dordrecht, The Netherlands, 1993; pp. 673-676.

14. Ma, L.Q.; Komar, K.M.; Tu, C.; Zhang, W.; Cai, Y.; Kennelley, E.D. A fern that hyperaccumulates arsenic. Nature 2001, 409, 579. [CrossRef] [PubMed]

15. Zhao, F.J.; Wang, J.R.; Barker, J.H.A.; Schat, H.; Bleeker, P.M.; McGrath, S.P. The role of phytochelatins in arsenic tolerance in the hyperaccumulator Pteris vittata. New Phytol. 2003, 159, 403-410. [CrossRef]

16. Xing, J.P.; Jiang, R.F.; Ueno, D.; Ma, J.F.; Schat, H.; McGrath, S.P.; Zhao, F.J. Variation in root-to-shoot translocation of cadmium and zinc among different accessions of the hyperaccumulators Thlaspi caerulescens and Thlaspi praecox. New Phytol. 2008, 178, 315-325. [CrossRef]

17. Zhao, F.J.; Jiang, R.F.; Dunham, S.J.; McGrath, S.P. Cadmium uptake, translocation and tolerance in the hyperaccumulator Arabidopsis halleri. New Phytol. 2006, 172, 646-654. [CrossRef]

18. Fasani, E.; DalCorso, G.; Varotto, C.; Li, M.; Visioli, G.; Mattarozzi, M.; Furini, A. The MTP1 promoters from Arabidopsis halleri reveal cis-regulating elements for the evolution of metal tolerance. New Phytol. 2017, 214, 1614-1630. [CrossRef]

19. Monica, R.C.; Cremonini, R. Nanoparticles and higher plants. Caryologia 2009, 62, 161-165. [CrossRef]

20. Steinitz, B.; Bilavendran, A.D. Thiosulfate stimulates growth and alleviates silver and copper toxicity in tomato root cultures. Plant Cell Tiss Organ Cult. 2011, 107, 355-363. [CrossRef]

21. Yan, A.; Chen, Z. Impacts of silver nanoparticles on plants: A focus on the phytotoxicity and underlying mechanism. Int. J. Mol. Sci. 2019, 20, 1003. [CrossRef]

22. Nowack, B.; Bucheli, T.D. Occurrence, behavior and effects of nanoparticles in the environment. Environ. Pollut. 2007, 150, 5-22. [CrossRef]

23. Gardea-Torresdey, J.L.; Parsons, J.G.; Gomez, E.; Peralta-Videa, J.; Troiani, H.E.; Santiago, P.; Yacaman, M.J. Formation and Growth of Au Nanoparticles inside Live Alfalfa Plants. Nano Lett. 2002, 2,397-401. [CrossRef]

24. Gardea-Torresdey, J.L.; Gomez, E.; Peralta-Videa, J.R.; Parsons, J.G.; Troiani, H.; Jose-Yacaman, M. Alfalfa sprouts: A natural source for the synthesis of silver nanoparticles. Langmuir 2003, 19, 1357-1361. [CrossRef]

25. Harris, A.T.; Bali, R. On the formation and extent of uptake of silver nanoparticles by live plants. J. Nanopart Res. 2008, 10, 691-695. [CrossRef]

26. Abdallah, B.B.; Zhang, X.; Andreu, I.; Gates, B.D.; El Mokni, R.; Rubino, S.; Landoulsi, A.; Chatti, A. Differentiation of Nanoparticles Isolated from Distinct Plant Species Naturally Growing in a Heavy Metal Polluted Site. J. Hazard. Mater. 2020, 386, 121644. [CrossRef] 
27. Thomine, S.; Schroeder, J.I. Plant Metal Transporters with Homology to Proteins of the NRAMP Family. In The Nramp Family; Cellier, M., Gros, P., Eds.; Springer US: New York, NY, USA, 2004.

28. Clemens, S.G.; Palmgren, M.; Krämer, U. A long way ahead: Understanding and engineering plant metal accumulation. TRENDS Plant Sci. 2002, 7, 309-315. [CrossRef]

29. Socha, A.L.; Guerinot, M. Lou Mn-euvering manganese: The role of transporter gene family members in manganese uptake and mobilization in plants. Front. Plant Sci. 2014, 5, 1-16. [CrossRef]

30. Milner, M.J.; Seamon, J.; Craft, E.; Kochian, L.V. Transport properties of members of the ZIP family in plants and their role in Zn and Mn homeostasis. J. Exp. Bot. 2013, 64, 369-381. [CrossRef]

31. Lin, Y.F.; Hassan, Z.; Talukdar, S.; Schat, H.; Aarts, M.G.M. Expression of the Znt1 zinc transporter from the metal hyperaccumulator Noccaea caerulescens confers enhanced zinc and cadmium tolerance and accumulation to Arabidopsis thaliana. PLoS ONE 2016, 11, 1-30. [CrossRef]

32. Takahashi, R.; Ishimaru, Y.; Senoura, T.; Shimo, H.; Ishikawa, S.; Arao, T.; Nakanishi, H.; Nishizawa, N.K. The OsNRAMP1 iron transporter is involved in Cd accumulation in rice. J. Exp. Bot. 2011, 62, 4843-4850. [CrossRef]

33. Vert, G.; Barberon, M.; Zelazny, E.; Séguéla, M.; Briat, J.F.; Curie, C. Arabidopsis IRT2 cooperates with the high-affinity iron uptake system to maintain iron homeostasis in root epidermal cells. Planta 2009, 229, 1171-1179. [CrossRef]

34. Migeon, A.; Blaudez, D.; Wilkins, O.; Montanini, B.; Campbell, M.M.; Richaud, P.; Thomine, S.; Chalot, M. Genome-wide analysis of plant metal transporters, with an emphasis on poplar. Cell. Mol. Life Sci. 2010, 67, 3763-3784. [CrossRef] [PubMed]

35. Liu, X.S.; Feng, S.J.; Zhang, B.Q.; Wang, M.Q.; Cao, H.W.; Rono, J.K.; Chen, X.; Yang, Z.M. OsZIP1 functions as a metal efflux transporter limiting excess zinc, copper and cadmium accumulation in rice. BMC Plant Biol. 2019, 19, 1-16. [CrossRef] [PubMed]

36. Pottier, M.; Oomen, R.; Picco, C.; Giraudat, J.; Scholz-Starke, J.; Richaud, P.; Carpaneto, A.; Thomine, S. Identification of mutations allowing Natural Resistance Associated Macrophage Proteins (NRAMP) to discriminate against cadmium. Plant J. 2015, 83, 625-637. [CrossRef] [PubMed]

37. Thomine, S.; Vert, G. Iron transport in plants: Better be safe than sorry. Curr. Opin. Plant Biol. 2013, 6, 322-327. [CrossRef]

38. Thomine, S.; Lelièvre, F.; Debarbieux, E.; Schroeder, J.I.; Barbier-Brygoo, H. AtNRAMP3, a multispecific vacuolar metal transporter involved in plant responses to iron deficiency. Plant J. 2003, 34, 685-695. [CrossRef]

39. Carter, C.; Pan, S.; Zouhar, J.; Avila, E.L.; Girke, T.; Raikhel, N.V. The vegetative vacuole proteome of Arabidopsis thaliana reveals predicted and unexpected proteins. Plant Cell 2004, 16, 3285-3303. [CrossRef]

40. Haney, C.J.; Grass, G.; Franke, S.; Rensing, C. New developments in the understanding of the cation diffusion facilitator family. J. Ind. Microbiol. Biotechnol. 2005, 32, 215-226. [CrossRef]

41. Gustin, J.L.; Zanis, M.J.; Salt, D.E. Structure and evolution of the plant cation diffusion facilitator family of ion transporters. BMC Evol. Biol. 2011, 11, 76. [CrossRef]

42. Ovečka, M.; Takáč, T. Managing heavy metal toxicity stress in plants: Biological and biotechnological tools. Biotechnol. Adv. 2014. [CrossRef]

43. Deng, F.; Yamaji, N.; Xia, J.; Ma, J.F. A Member of the heavymetal P-type ATPase OsHMA5 is involved in xylem loading of copper in rice. Plant Physiol. 2013, 163, 1353-1362. [CrossRef]

44. Gomes, D.; Agasse, A.; Thiébaud, P.; Delrot, S.; Gerós, H.; Chaumont, F. Aquaporins are multifunctional water and solute transporters highly divergent in living organisms. BBA-BIOMEMBRANES 2009, 1788, 1213-1228. [CrossRef]

45. Hove, R.M.; Bhave, M. Plant aquaporins with non-aqua functions: Deciphering the signature sequences. Plant Mol. Biol. 2011, 75, 413-430. [CrossRef] [PubMed]

46. Hachez, C.; Veljanovski, V.; Reinhardt, H.; Guillaumot, D.; Vanhee, C.; Chaumont, F.; Batoko, H. The Arabidopsis Abiotic Stress-Induced Tspo-Related Protein Reduces Cell-Surface Expression of the Aquaporin PIP2;7 through Protein-Protein Interactions and Autophagic Degradation. Plant Cell 2014, 26, 4974-4990. [CrossRef] [PubMed]

47. Chevalier, A.; Chaumont, F. Trafficking of Plant Plasma Membrane Aquaporins: Multiple Regulation Levels and Complex Sorting Signals. Plant Cell Physiol. 2015, 56, 819-829. [CrossRef] [PubMed] 
48. Barozzi, F.; Papadia, P.; Stefano, G.; Renna, L.; Brandizzi, F.; Migoni, D.; Fanizzi, F.P.; Piro, G.; Di Sansebastiano, G.P. Variation in membrane trafficking linked to SNARE AtSYP51 interaction with aquaporin NIP1;1. Front. Plant Sci. 2019, 9, 1949. [CrossRef] [PubMed]

49. Quigley, F.; Rosenberg, J.M.; Shachar-Hill, Y.; Bohnert, H.J. From genome to function: The Arabidopsis aquaporins. Genome Biol. 2001, 3, 1-17. [CrossRef]

50. Gupta, A.B.; Sankararamakrishnan, R. Genome-wide analysis of major intrinsic proteins in the tree plant Populus trichocarpa: Characterization of XIP subfamily of aquaporins from evolutionary perspective. BMC Plant Biol. 2009, 9, 134. [CrossRef]

51. Maathuis, F.J.M.; Filatov, V.; Herzyk, P.; Krijger, G.C.; Axelsen, K.B.; Chen, S.; Green, B.J.; Li, Y.; Madagan, K.L.; Sánchez-Fernández, R.; et al. Transcriptome analysis of root transporters reveals participation of multiple gene families in the response to cation stress. Plant J. 2003, 35, 675-692. [CrossRef]

52. Boursiac, Y.; Chen, S.; Luu, D.; Sorieul, M.; Van Den Dries, N.; Maurel, C. Early Effects of Salinity on Water Transport in Arabidopsis Roots. Molecular and Cellular Features of Aquaporin Expression. Plant Physiol. 2005, 139, 790-805. [CrossRef]

53. Yamaguchi, H.; Fukuoka, H.; Arao, T.; Ohyama, A.; Nunome, T.; Miyatake, K.; Negoro, S. Gene expression analysis in cadmium-stressed roots of a low cadmium-accumulating solanaceous plant, Solanum torvum. J. Exp. Bot. 2010, 61, 423-437. [CrossRef]

54. Zhang, Y.; Wang, Z.; Chai, T.; Wen, Z.; Zhang, H. Indian mustard aquaporin improves drought and heavy-metal resistance in tobacco. Mol. Biotechnol. 2008, 40, 280-292. [CrossRef] [PubMed]

55. Vera-Estrella, R.; Barkla, B.J.; Bohnert, H.J.; Pantoja, O. Novel regulation of aquaporins during osmotic stress. Plant Physiol. 2004, 135, 2318-2329. [CrossRef] [PubMed]

56. Lee, H.J.; Kim, Y.T.; Kang, W.J.; Lee, H.J.; Kang, C.H.; Kim, J.H. Integrated positron-emission tomography for nodal staging in lung cancer. Asian Cardiovasc. Thorac. Ann. 2009, 17, 622-626. [CrossRef]

57. Rauser, W.E. Structure and function of metal chelators produced by plants: The case for organic acids, amino acids, phytin, and metallothioneins. Cell Biochem. Biophys. 1999, 31, 19-48. [CrossRef] [PubMed]

58. Prévéral, S.; Ansoborlo, E.; Mari, S.; Vavasseur, A.; Forestier, C. Metal(loid)s and radionuclides cytotoxicity in Saccharomyces cerevisiae. Role of YCF1, glutathione and effect of buthionine sulfoximine. Biochimie 2006, 88, 1651-1663. [CrossRef]

59. Kozhevnikova, A.D.; Seregin, I.V.; Erlikh, N.T.; Shevyreva, T.A.; Andreev, I.M.; Verweij, R.; Schat, H. Histidine-mediated xylem loading of zinc is a species-wide character in Noccaea caerulescens. New Phytol. 2014, 203, 508-519. [CrossRef]

60. Leitenmaier, B.; Küpper, H. Compartmentation and complexation of metals in hyperaccumulator plants. Front. Plant Sci. 2013, 4, 1-13. [CrossRef]

61. Curie, C.; Cassin, G.; Couch, D.; Divol, F.; Higuchi, K.; Le Jean, M.; Misson, J.; Schikora, A.; Czernic, P.; Mari, S. Metal movement within the plant: Contribution of nicotianamine and yellow stripe 1-like transporters. Ann. Bot. 2009, 103, 1-11. [CrossRef] [PubMed]

62. Krzesłowska, M. The cell wall in plant cell response to trace metals: Polysaccharide remodeling and its role in defense strategy. Acta Physiol. Plant. 2011, 33, 35-51. [CrossRef]

63. Zhang, J.; Martinoia, E.; Lee, Y. Vacuolar transporters for cadmium and arsenic in plants and their applications in phytoremediation and crop development. Plant Cell Physiol. 2018, 59, 1317-1325. [CrossRef]

64. Gardarin, A.; Chédin, S.; Lagniel, G.; Aude, J.C.; Godat, E.; Catty, P.; Labarre, J. Endoplasmic reticulum is a major target of cadmium toxicity in yeast. Mol. Microbiol. 2010, 76, 1034-1048. [CrossRef] [PubMed]

65. Yokouchi, M.; Hiramatsu, N.; Hayakawa, K.; Kasai, A.; Takano, Y.; Yao, J.; Kitamura, M. Atypical, bidirectional regulation of cadmium-induced apoptosis via distinct signaling of unfolded protein response. Cell Death Differ. 2007, 14, 1467-1474. [CrossRef] [PubMed]

66. Kolaj-Robin, O.; Russell, D.; Hayes, K.A.; Pembroke, J.T.; Soulimane, T. Cation diffusion facilitator family: Structure and function. FEBS Lett. 2015, 589, 1283-1295. [CrossRef] [PubMed]

67. Wierzbicka, M.H.; Przedpełska, E.; Ruzik, R.; Ouerdane, L.; Połeć-Pawlak, K.; Jarosz, M.; Szpunar, J.; Szakiel, A. Comparison of the toxicity and distribution of cadmium and lead in plant cells. Protoplasma 2007, 231, 99-111. [CrossRef]

68. Ji, R.; Zhou, L.; Liu, J.; Wang, Y.; Yang, L.; Zheng, Q.; Zhang, C.; Zhang, B.; Ge, H.; Yang, Y.; et al. Calcium-dependent protein kinase CPK31 interacts with arsenic transporter AtNIP1;1 and regulates arsenite uptake in Arabidopsis thaliana. PLoS ONE 2017, 12, 1-20. [CrossRef] 
69. Li, J.; Jia, Y.; Dong, R.; Huang, R.; Liu, P.; Li, X.; Wang, Z.; Liu, G.; Chen, Z. Advances in the mechanisms of plant tolerance to manganese toxicity. Int. J. Mol. Sci. 2019, 20, 5096. [CrossRef]

70. Mills, R.F.; Doherty, M.L.; López-Marqués, R.L.; Weimar, T.; Dupree, P.; Palmgren, M.G.; Pittman, J.K.; Williams, L.E. ECA3, a golgi-localized P2A-type ATPase, plays a crucial role in manganese nutrition in Arabidopsis. Plant Physiol. 2008, 146, 116-128. [CrossRef]

71. Luo, Z.B.; He, J.; Polle, A.; Rennenberg, H. Heavy metal accumulation and signal transduction in herbaceous and woody plants: Paving the way for enhancing phytoremediation efficiency. Biotechnol. Adv. 2016, 34, 1131-1148. [CrossRef]

72. Delhaize, E.; Gruber, B.D.; Pittman, J.K.; White, R.G.; Leung, H.; Miao, Y.; Jiang, L.; Ryan, P.R.; Richardson, A.E. A role for the AtMTP11 gene of Arabidopsis in manganese transport and tolerance. Plant J. 2007, 51, 198-210. [CrossRef]

73. Tsunemitsu, Y.; Yamaji, N.; Ma, J.F.; Kato, S.I.; Iwasaki, K.; Ueno, D. Rice reduces Mn uptake in response to Mn stress. Plant Signal. Behav. 2018, 13. [CrossRef]

74. Peiter, E.; Montanini, B.; Gobert, A.; Pedas, P.; Husted, S.; Maathuis, F.J.M.; Blaudez, D.; Chalot, M.; Sanders, D. A secretory pathway-localized cation diffusion facilitator confers plant manganese tolerance. Proc. Natl. Acad. Sci. USA 2007, 104, 8532-8537. [CrossRef] [PubMed]

75. Puente-Sánchez, F.; Olsson, S.; Aguilera, A. Comparative Transcriptomic Analysis of the Response of Dunaliella acidophila (Chlorophyta) to Short-Term Cadmium and Chronic Natural Metal-Rich Water Exposures. Microb. Ecol. 2016, 72, 595-607. [CrossRef] [PubMed]

76. Perales-Vela, H.V.; Peña-Castro, J.M.; Cañizares-Villanueva, R.O. Heavy metal detoxification in eukaryotic microalgae. Chemosphere 2006, 64, 1-10. [CrossRef] [PubMed]

77. Eleftheriou, E.P.; Adamakis, I.D.S.; Panteris, E.; Fatsiou, M. Chromium-induced ultrastructural changes and oxidative stress in roots of Arabidopsis thaliana. Int. J. Mol. Sci. 2015, 16, 15852-15871. [CrossRef]

78. Wan, L.; Zhang, H. Cadmium toxicity Effects on cytoskeleton, vesicular trafficking and cell wall construction. Plant Signal. Behav. 2012, 7, 1-4. [CrossRef]

79. Wang, X.; Zhang, S.; Gao, Y.; Lü, W.; Sheng, X. Different heavy metals have various effects on Picea wilsonii pollen germination and tube growth. Plant Signal. Behav. 2015, 10, 1-4. [CrossRef]

80. Kulich, I.; Žárský, V. Autophagy-related direct membrane import from ER/Cytoplasm into the vacuole or apoplast: A hidden gateway also for secondary metabolites and phytohormones? Int. J. Mol. 2014, 15, 7462-7474. [CrossRef]

81. Sharma, S.S.; Dietz, K.J.; Mimura, T. Vacuolar compartmentalization as indispensable component of heavy metal detoxification in plants. Plant Cell Environ. 2016, 39, 1112-1126. [CrossRef]

82. Barozzi, F.; Di Sansebastiano, G.P.; Sabella, E.; Aprile, A.; Piro, G.; De Bellis, L.; Nutricati, E. Glutathione S-transferase related detoxification processes are correlated with receptor-mediated vacuolar sorting mechanisms. Plant Cell Rep. 2017, 36, 1361-1373. [CrossRef]

83. Faraco, M.; Li, Y.; Li, S.; Spelt, C.; Di Sansebastiano, G.P.; Reale, L.; Ferranti, F.; Verweij, W.; Koes, R.; Quattrocchio, F.M. A Tonoplast P3B-ATPase Mediates Fusion of Two Types of Vacuoles in Petal Cells. Cell Rep. 2017, 19, 2413-2422. [CrossRef]

84. Liu, F.; Hu, W.; Vierstra, R.D. The vacuolar protein sorting-38 subunit of the Arabidopsis phosphatidylinositol-3-kinase complex plays critical roles in autophagy, endosome sorting, and gravitropism. Front. Plant Sci. 2018, 9, 1-22. [CrossRef] [PubMed]

85. Ariani, A.; Barozzi, F.; Sebastiani, L.; Di Toppi, L.S.; Di Sansebastiano, G.P.; Andreucci, A. AQUA1 is a mercury sensitive poplar aquaporin regulated at transcriptional and post-translational levels by $\mathrm{Zn}$ stress. Plant Physiol. Biochem. 2019, 135, 588-600. [CrossRef] [PubMed]

86. Di Baccio, D.; Galla, G.; Bracci, T.; Andreucci, A.; Barcaccia, G.; Tognetti, R.; Sebastiani, L. Transcriptome analyses of Populus $\times$ euramericana clone I-214 leaves exposed to excess zinc. Tree Physiol. 2011, 31, 1293-1308. [CrossRef] [PubMed]

87. Sebastiani, L.; Scebba, F.; Tognetti, R. Heavy metal accumulation and growth responses in poplar clones Eridano (Populus deltoides $\times$ maximowiczii) and I-214 (P. $\times$ euramericana) exposed to industrial waste. Environ. Exp. Bot. 2004, 52, 79-88. [CrossRef]

88. Moeller, H.B.; Fenton, R.A. Cell biology of vasopressin-regulated aquaporin-2 trafficking. Pflug. Arch. 2012, 464, 133-144. [CrossRef] 
89. Boursiac, Y.; Prak, S.; Boudet, J.; Postaire, O.; Luu, D.T.; Tournaire-Roux, C.; Santoni, V.; Maurel, C. The response of Arabidopsis root water transport to a challenging environment implicates reactive oxygen speciesand phosphorylation-dependent internalization of aquaporins. Plant Signal. Behav. 2008, 3, 1096-1098. [CrossRef]

90. Devirgiliis, C.; Murgia, C.; Danscher, G.; Perozzi, G. Exchangeable zinc ions transiently accumulate in a vesicular compartment in the yeast Saccharomyces cerevisiae. BBRC 2004, 323, 58-64. [CrossRef]

91. Eide, D.J. Zinc transporters and the cellular trafficking of zinc. BBA 2006, 1763, 711-722. [CrossRef]

92. Desbrosses-Fonrouge, A.G.; Voigt, K.; Schröder, A.; Arrivault, S.; Thomine, S.; Krämer, U. Arabidopsis thaliana MTP1 is a $\mathrm{Zn}$ transporter in the vacuolar membrane which mediates $\mathrm{Zn}$ detoxification and drives leaf $\mathrm{Zn}$ accumulation. FEBS Lett. 2005, 579, 4165-4174. [CrossRef]

93. Morel, M.; Crouzet, J.; Gravot, A.; Auroy, P.; Leonhardt, N.; Vavasseur, A.; Richaud, P. AtHMA3, a P1B-ATPase allowing $\mathrm{Cd} / \mathrm{Zn} / \mathrm{Co} / \mathrm{Pb}$ vacuolar storage in Arabidopsis. Plant Physiol. 2009, 149, 894-904. [CrossRef]

94. Kawachi, M.; Kobae, Y.; Mori, H.; Tomioka, R.; Lee, Y.A.; Maeshima, M. A Mutant Strain Arabidopsis thaliana that Lacks Vacuolar Membrane Zinc Transporter MTP1 Revealed the Latent Tolerance to Excessive Zinc. Plant Cell Physiol. 2009, 50, 1156-1170. [CrossRef] [PubMed]

95. Delhaize, E.; Kataoka, T.; Hebb, D.M.; White, R.G.; Ryan, P.R. Genes encoding proteins of the cation diffusion facilitator family that confer manganese tolerance. Plant Cell 2003, 15, 1131-1142. [CrossRef] [PubMed]

96. Kawachi, M.; Kobae, Y.; Mimura, T.; Maeshima, M. Deletion of a histidine-rich loop of AtMTP1, a vacuolar $\mathrm{Zn}^{2+} / \mathrm{H}^{+}$antiporter of Arabidopsis thaliana, stimulates the transport activity. J. Biol. Chem. 2008, 283, 8374-8383. [CrossRef] [PubMed]

97. Tuszynska, S.; Davies, D.; Turnau, K.; Ashford, A.E. Changes in vacuolar and mitochondrial motility and tubularity in response to zinc in a Paxillus involutus isolate from a zinc-rich soil. Fungal Genet. Biol. 2006, 43, 155-163. [CrossRef]

98. Davies, K.L.; Davies, M.S.; Francis, D. Zinc-induced vacuolation in root meristematic cells of Festuca rubra L. Ann. Bot. 1992, 69, 21-24. [CrossRef]

99. Nishikawa, K.; Yamakoshi, Y.; Uemura, I.; Tominaga, N. Ultrastructural changes in Chlamydomonas acidophila (Chlorophyta) induced by heavy metals and polyphosphate metabolism. FEMS Microbiol. Ecol. 2003, 44, 253-259. [CrossRef]

100. Fan, J.L.; Wei, X.Z.; Wan, L.C.; Zhang, L.Y.; Zhao, X.Q.; Liu, W.Z.; Hao, H.Q.; Zhang, H.Y. Disarrangement of actin filaments and $\mathrm{Ca}^{2+}$ gradient by $\mathrm{CdCl} 2$ alters cell wall construction in Arabidopsis thaliana root hairs by inhibiting vesicular trafficking. J. Plant Physiol. 2011, 168, 1157-1167. [CrossRef]

101. Reese, N.; Mccall, D.; Roberts, L. Cadmium - induced ultrastructural changes in suspension-cultured tobacco cells (Nicotiana tabacum L. var. xanthi). Environ. Exp. Bot. 1986, 26, 169-173. [CrossRef]

102. Vitória, A.P.; Da Cunha, M.; Azevedo, R.A. Ultrastructural changes of radish leaf exposed to cadmium. Environ. Exp. Bot. 2006, 58, 47-52. [CrossRef]

103. Parrotta, L.; Guerriero, G.; Sergeant, K.; Cai, G.; Hausman, J.F. Target or barrier? The cell wall of early- and later-diverging plants vs cadmium toxicity: Differences in the response mechanisms. Front. Plant Sci. 2015, 6, 1-16. [CrossRef]

104. Le Gall, H.; Philippe, F.; Domon, J.M.; Gillet, F.; Pelloux, J.; Rayon, C. Cell wall metabolism in response to abiotic stress. Plants 2015, 4, 112-166. [CrossRef] [PubMed]

105. Jiang, X.; Wang, C. Zinc distribution and zinc-binding forms in Phragmites australis under zinc pollution. J. Plant Physiol. 2008, 165, 697-704. [CrossRef] [PubMed]

106. Colzi, I.; Doumett, S.; Del Bubba, M.; Fornaini, J.; Arnetoli, M.; Gabbrielli, R.; Gonnelli, C. On the role of the cell wall in the phenomenon of copper tolerance in Silene paradoxa L. Environ. Exp. Bot. 2011, 72, 77-83. [CrossRef]

107. Krzesłowska, M.; Lenartowska, M.; Mellerowicz, E.J.; Samardakiewicz, S.; Woźny, A. Pectinous cell wall thickenings formation-A response of moss protonemata cells to lead. Environ. Exp. Bot. 2009, 65, 119-131. [CrossRef]

108. Probst, A.; Liu, H.; Fanjul, M.; Liao, B.; Hollande, E. Response of Vicia faba L. to metal toxicity on mine tailing substrate: Geochemical and morphological changes in leaf and root. Environ. Exp. Bot. 2009, 66, 297-308. [CrossRef]

109. Liu, H.; Liao, B.; Lu, S. Toxicity of surfactant, acid rain and $\mathrm{Cd}^{2+}$ combined pollution to the nucleus of Vicia faba root tip cells. J. Appl. Ecol. 2004, 15, 493-496. [CrossRef] 
110. Konno, H.; Nakashima, S.; Katoh, K. Metal-tolerant moss Scopelophila cataractae accumulates copper in the cell wall pectin of the protonema. J. Plant Physiol. 2010, 167, 358-364. [CrossRef]

111. Salt, D.E.; Prince, R.C.; Baker, A.J.M.; Raskin, I.; Pickering, I.J. Zinc ligands in the metal hyperaccumulator Thlaspi caerulescens as determined using x-ray absorption spectroscopy. J. Environ. Sci. Technol. 1999, 33, 713-717. [CrossRef]

112. Konno, H.; Nakato, T.; Nakashima, S.; Katoh, K. Lygodium japonicum fern accumulates copper in the cell wall pectin. J. Exp. Bot. 2005, 56, 1923-1931. [CrossRef]

113. Nyquist, J.; Greger, M. Uptake of $\mathrm{Zn}, \mathrm{Cu}$, and Cd in metal loaded Elodea canadensis. Environ. Exp. Bot. 2007, 60, 219-226. [CrossRef]

114. Elobeid, M.; Göbel, C.; Feussner, I.; Polle, A. Cadmium interferes with auxin physiology and lignification in poplar. J. Exp. Bot. 2012, 63, 1413-1421. [CrossRef] [PubMed]

115. Cheng, H.; Jiang, Z.Y.; Liu, Y.; Ye, Z.H.; Wu, M.L.; Sun, C.C.; Sun, F.L.; Fei, J.; Wang, Y.S. Metal (Pb, Zn and $\mathrm{Cu})$ uptake and tolerance by mangroves in relation to root anatomy and lignification/suberization. Tree Physiol. 2014, 34, 646-656. [CrossRef] [PubMed]

116. Claus, H. Laccases: Structure, reactions, distribution. Micron 2004, 35, 93-96. [CrossRef] [PubMed]

117. Ali, M.B.; Singh, N.; Shohael, A.M.; Hahn, E.J.; Paek, K.Y. Phenolics metabolism and lignin synthesis in root suspension cultures of Panax ginseng in response to copper stress. Plant Sci. 2006, 171, 147-154. [CrossRef]

118. Chandran, D.; Sharopova, N.; Ivashuta, S.; Gantt, J.S.; VandenBosch, K.A.; Samac, D.A. Transcriptome profiling identified novel genes associated with aluminum toxicity, resistance and tolerance in Medicago truncatula. Planta 2008, 228, 151-166. [CrossRef]

119. Barceló, J.; Poschenrieder, C. Plant water relations as affected by heavy metal stress: A review. J. Plant Nutr. 1990, 13, 1-37. [CrossRef]

120. Uemura, T.; Ueda, T. Plant vacuolar trafficking driven by RAB and SNARE proteins. Curr. Opin. Plant Biol. 2014, 22, 116-121. [CrossRef]

121. Fasani, E.; Manara, A.; Martini, F.; Furini, A.; DalCorso, G. The potential of genetic engineering of plants for the remediation of soils contaminated with heavy metals. Plant Cell Environ. 2017, 41, 1201-1232.

(C) 2020 by the authors. Licensee MDPI, Basel, Switzerland. This article is an open access article distributed under the terms and conditions of the Creative Commons Attribution (CC BY) license (http://creativecommons.org/licenses/by/4.0/). 